\title{
Functionality of Films from Nigella sativa Defatted Seed Cake Proteins Plasticized with Grape Juice: Use in Wrapping Sweet Cherries
}

\author{
Dana Yaseen ${ }^{1}$, Mohammed Sabbah ${ }^{1, *(D)}$, Asmaa Al-Asmar ${ }^{2}$ (D), Mohammad Altamimi ${ }^{1}$ (D), Michela Famiglietti ${ }^{3}$, \\ C. Valeria L. Giosafatto ${ }^{3,4}$ (D) and Loredana Mariniello ${ }^{3,4}$ (ID
}

1 Department of Nutrition and Food Technology, An-Najah National University, P.O. Box 7, Nablus P400, Palestine; danayaseen1@gmail.com (D.Y.); m.altamimi@najah.edu (M.A.)

2 An-Najah BioSciences Unit (NBU), An-Najah National University, P.O. Box 7, Nablus P400, Palestine; a.alasmar@najah.edu

3 Department of Chemical Sciences, University of Naples “Federico II", 80126 Naples, Italy; michela.famiglietti@unina.it (M.F.); giosafat@unina.it (C.V.L.G.); loredana.mariniello@unina.it (L.M.)

4 Center for Studies on Bioinspired Agro-Environmental Technology (BAT), University of Naples "Federico II", 80126 Naples, Italy

* Correspondence: m.sabbah@najah.edu; Tel.: +790-92345115

Citation: Yaseen, D.; Sabbah, M.;

Al-Asmar, A.; Altamimi, M.;

Famiglietti, M.; Giosafatto, C.V.L.; Mariniello, L. Functionality of Films from Nigella sativa Defatted Seed Cake Proteins Plasticized with Grape Juice: Use in Wrapping Sweet Cherries. Coatings 2021, 11, 1383. https:// doi.org/10.3390/coatings11111383

Received: 20 October 2021

Accepted: 9 November 2021

Published: 12 November 2021

Publisher's Note: MDPI stays neutral with regard to jurisdictional claims in published maps and institutional affiliations.

Copyright: (c) 2021 by the authors. Licensee MDPI, Basel, Switzerland. This article is an open access article distributed under the terms and conditions of the Creative Commons Attribution (CC BY) license (https:// creativecommons.org/licenses/by/ $4.0 /)$.

\begin{abstract}
The main aim of this work is to improve the functionality of Nigella sativa protein concentrate (NSPC) films by using grape juice (GJ). The film's mechanical, antioxidant, and antimicrobial activities were evaluated. The obtained results showed, for the first time, that GJ at concentrations of $2 \%-10 \%(v / v)$ are able to act as plasticizer for the NSPC films with promising film properties. The results showed that the tensile strength and Young's modulus of NSPC films were reduced significantly when the GJ increased. However, the NSPC films prepared with 6\% GJ observed a higher elongation at break compared with other films. Moreover, the obtained films showed very interesting and promising results for their antioxidant and antimicrobial properties compared with the control films. The sweet cherries wrapped with NSPC film showed that the TSS (Brix) was significantly lower compared to the control, after 10 days of storage. However, the titratable acidity, $\mathrm{pH}$ value, and $L^{*}$ of all cherries, either wrapped or not, was not significantly different in all storage times. On the other hand, hue angle was significantly lower after 10 days of storage at $-18^{\circ} \mathrm{C}$ compared with control films. GJ has a multi-functional effect for protein-based films as plasticizer, antioxidant, and antimicrobial function.
\end{abstract}

Keywords: edible film; Nigella sativa; sweet cherry; grape juice; functional edible films

\section{Introduction}

Today we are living in an era called a "plastic age", in which plastic pollution has become one of the most urgent environmental issues, with plastic production increasing exponentially, from 2.3 million tons in 1950 to 448 million tons in 2015. Production is expected to double by 2050. Approximately 1 million plastic bottles are sold every minute worldwide, according to National Geographic, and the oceans contain 18 billion pounds of plastic every year [1,2]. The ubiquitous presence of plastic has some strong and valid reasons such as its durability, flexibility, and cheapness, due to some additives that make it stronger, more flexible, and durable, so plastic products may take hundreds of years to degrade. However, it is now not hidden that the overuse and disposal of plastic are becoming a major threat to Earth's environment. Unnecessary use of plastic, improper dumping, excessive use of single-use plastics, and lack of awareness are some of the factors responsible for the current condition of the world's ecosystems.

In recent decades, concerns surrounding conventional plastics have stimulated a focus of attention on environmentally friendly, non-toxic, and biodegradable materials 
derived from natural ingredients such as polysaccharides, lipids, and proteins due to their sustainable supply and biodegradable potential [3,4].

Biodegradation refers to the ability of materials to degrade and return to nature within a short period of time after they are disposed of-typically a year or less [5]. Natural polymers derived from agricultural products (such as polysaccharides, proteins, and plant oils) are the main resource for the development of renewable and biodegradable or edible films polymer materials. The edible films can be integral part of foods and can be consumed with products, so there is no packaging and no disposed material [6,7]. It may also be incorporated with some different bioactive compounds such as virgin coconut oil [8], oregano essential oil [9,10], thyme essential oil [10], cloves [11], lacto peroxidase enzyme [12], pomegranate peel extract [13], and others, which act as an antimicrobial and antioxidant agent in edible coatings or films to maintain food safety and quality and enhance the shelf life of food products. The mechanical and barrier properties of edible films depend on many factors, such as the biopolymer sources, concentration, and viscosity [14]. For example, films based on proteins or polysaccharides have very efficient oxygen and carbon dioxide barriers; whereas, their resistance to water vapor transmission is limited. Multicomponent films have also been manufactured in an attempt to combine the advantages of individual materials with film forming.

Seeds are classified as the main source of protein and other important nutrients for supporting health and well-being. Seeds are not only used for nutrition but can also be used in traditional medicine or herbal medicine for their pharmacological properties. Many pharmacological applications derive from these bioactive components [15]. Physicians always endeavor to find drugs with fewer side effects. Nigella sativa (N. sativa) belongs to the Ranunculaceae family and has a spiritual and historical background that makes it one of the most promising therapeutic plants. It is cultivated in many countries but is native to Southern Europe, Southeast Asia, and Southwest Asia, and is grown as a spice or for its medicinal value $[16,17]$. The flowers may be white, pale blue, or dark blue, and the plant is self-branching [18]. Its seeds are mainly used as a condiment and as a relieving agent for different ailments [19-21].

Black seed can be used as directed or active ingredients in herbal medicines or as herbal tea. N. sativa seed is extracted, and its extracted oil may be exploited in traditional medicine to treat a wide range of ailments such as diabetes, hypertension, oxidative stress, epilepsies, ulcers, asthma, inflammatory disorders, and cancers in model organisms, as well as in human beings [22-29]. Some of the bioactive compounds obtained from $N$. sativa have been identified and studies have shown that the biological activity of $N$. sativa seeds is mainly attributed to its essential oil component, thymoquinone [30,31], which is a major phytochemical in N. sativa, and widely considered to be most important for the broad-spectrum medicinal properties of this valuable plant. Other phytochemicals from different varieties of $N$. sativa include sterols, saponins, phenolic compounds, various alkaloids, as well as volatile oils of different compositions [32,33].

Huge quantities of $N$. sativa defatted cake are produced as by-products and most of it is served as animal feed due to the high bioactive materials and protein content [34]. The N. sativa proteins' hydro-methanolic fraction account for about $35 \%-40 \%$ of the total dry weight and it separates into ranges from 10 to $94 \mathrm{kDa}$ on sodium dodecyl sulphatepolyacrylamide gel electrophoresis (SDS-PAGE) [35]. Despite its high pharmacological activity, this fraction has been found to exert effects independent of those exerted by volatile oils, and its effects on human health are receiving increasing attention. Based on research, this extract functions as an effective sedative and has depressant effects on the central nervous system, induces analgesia, prevents progression of pathological changes in the lungs, and decreases blood cytokines in the body [36,37]. In a recent paper by Sabbah et al. [38] the use of proteins from N. sativa oilcakes to prepare ecofriendly materials was also investigated [38]. The authors investigated the possibility of preparing hydrocolloid films from proteins obtained from N. sativa defatted seed cake (NSDSC), when 
the latter were modified by means of the enzyme microbial transglutaminase, and they characterized the produced materials from a biological and technological point of view.

Among the most popular fruits by consumers, sweet cherry (Prunus avium L.) is known for its high nutritional content and is mostly eaten raw. Several epidemiological studies have recently demonstrated the health-promoting effects related to its content of phytochemicals such as ascorbic acid, anthocyanin, and phenolic compounds [39]. The main characteristics related to the quality of cherry fruits are color, sweetness, sourness, and firmness [40]. Consumer acceptance of sweet cherry depend mainly on the sugar and acid concentrations [41]. Nutritionally, sweet cherries have a higher content of simple sugars (13 g/100 g). Cherries contain water-soluble vitamins (C, B), fat-soluble vitamins (A, E, K), and some carotenoids, in particular beta-carotene. Cherries also contain minerals such as magnesium, calcium, phosphorous, and potassium (10, 14, 20, $200 \mathrm{mg} / 100 \mathrm{~g}$, respectively). As a result of the high respiration rate and metabolic activity of sweet cherries, they deteriorate rapidly after harvest, causing diminished acidity and phytochemical content, weight loss, and color change [42]. To maintain the good quality of the fruits, it is necessary to work to extend the shelf life of sweet cherries and to maintain the necessary packaging and storage. There are many studies on extending the shelf life of sweet cherries that are gaining great importance. Various techniques such as cold storage, controlled atmosphere storage, modified atmosphere packaging, and edible film coating have been used to maintain the quality and extend the shelf life of sweet cherries after harvest [43-45]. Nowadays, frozen sweet cherries become very popular around the world, and one of the common food quality degradations of frozen food is the freezer burn that occur due to moisture migration in frozen foods. The product appearance becomes glassy due to the evaporating of the ice crystals from the surface area of a products and brownish spots occurring on the food surface that cause the tissue to become dry and tough. The way to help to prevent the freezer burn is by using plastic packaging during the freezing process or to separate the food surfaces from the freezer environment [46].

Grapes (Vitis vinifera) is a widely cultivated crop in the world, native to the Mediterranean region and Central Asia. Grapes are non-climacteric fruits for fresh consumption and are botanical groups of true berries. Turkey is an important grape-producing country and is the fifth largest producer of grapes in the world. Since grapes have a very short shelf life, large amounts of grape loss occur due to deterioration. For this reason, grapes must be processed in a form that can be stored for a long time without loss of the nutritional value. Grapes are one of the most widespread fruit crops worldwide and their composition and properties have been extensively studied, with several reports of the presence of large amounts of phenolic compounds [47]. Most of the phenolic compounds in grapes can act as antioxidants [48]. Similarly, wine production residues are also characterized by high contents of phenolic compounds due to their incomplete extraction during wine production $[49,50]$. By-products obtained after the production of wine, (seeds and pomace) constitute a cheap source for extracting antioxidant compounds, providing important economic advantages [51]. The composition of grapes mainly consists of $(w / w) 40 \%$ fiber, $16 \%$ essential oil, $11 \%$ protein, and $7 \%$ complex phenolic compounds such as tannins, sugars, minerals, and other substances [52]. Grape skin is a source of anthocyanidins and anthocyanins, which are natural pigments with antioxidant properties that act by inhibiting lipid oxidation and also have anti-mutagenic activities [53]. In addition, they are excellent sources of vitamins A, C, K, carotenes, flavonoids, and B-complex vitamins such as pyridoxine, riboflavin, and thiamine.

The main objective of this study was to produce edible films using the protein extracted from Nigella sativa defatted seed cakes, functionalized with different concentrations of natural grape juice. The obtained films were evaluated for their mechanical properties as well as for the water content, water uptake, antioxidant activity, and antimicrobial activity. Despite the high biological value of these proteins [54], there are no studies about the shelf-life of foods when protected by NSDSC proteins-based materials. Therefore, in this work, the films with the best properties were selected to wrap the sweet cherries and the 
quality of unwrapped and wrapped frozen cherries $\left(-18^{\circ} \mathrm{C}\right)$, stored at different times, was evaluated.

\section{Materials and Methods}

\subsection{Materials}

The grapes (Vitis vinifera) were harvested, washed, had their seeds removed, and their juice extracted with a fruit juicer. The juice was filtrated with cheesecloth to separate the skins and stored at $-20^{\circ} \mathrm{C}$ until usage. Sweet cherries (Prunus avium L., cv Sweetheart) were obtained from a local market in Nablus, Palestine transported, and stored at room temperature until treatment. Nigella sativa defatted seed cake (NSDSC) was purchased from Alhathnawi General Trade Co. (Jenin, Palestine). All chemicals, BBL ${ }^{\mathrm{TM}}$ Mannitol Salt Agar and other solvents used in this study were obtained from Sigma-Aldrich Company (St. Louis, MO, USA). Mueller Hinton Broth Himedia M391 $500 \mathrm{~g}$ was obtained from HiMedia Leading BioSciences Company (Mumbai, India). Bacterial strains from American Type Culture Collection were Staphylococcus aureus (ATCC 25923), Pseudomonas aeruginosa (ATCC 27853), Escherichia coli (ATCC 25922), Klebsiella pneumonia (ATCC 13883), and Enterococcus faecium (ATCC 700221), while Salmonella typhi were obtained from the microbiology laboratory of An-Najah National University (Nablus, Palestine).

\subsection{Methods}

\subsubsection{Protein Extraction}

The proteins were extracted from NSDSC by the acid-base extraction method, as previously described [55], with some modifications. After dispersing the dry powder, NSDSC, in distilled water at a ratio of $1: 10, \mathrm{w} / \mathrm{v}$, the $\mathrm{pH}$ was adjusted to 12.0 by adding $1 \mathrm{~N} \mathrm{NaOH}$ and stirring at medium speed at room temperature for $2 \mathrm{~h}$. Supernatant was obtained from centrifugation at $4000 \mathrm{rpm}$ for $20 \mathrm{~min}$, and the $\mathrm{pH}$ was adjusted at 5.4 with $1 \mathrm{~N} \mathrm{HCl}$ to precipitate the protein, which was then picked up and dried at $30^{\circ} \mathrm{C}$ and $20 \%$ relative humidity $(\mathrm{RH})$. The obtained protein concentrate was finely ground by using an electrical miller and stored inside an airtight container at room temperature.

\subsubsection{Proximate Analysis}

NSDSC and N. sativa protein concentrate (NSPC) was analyzed for its proximate. Moisture content was measured by using infrared moisture analyzer (Sartorius ${ }^{\mathrm{TM}}$ MA100C, Sartorius, Goettingen, Germany), the temperature was $105{ }^{\circ} \mathrm{C}$, where applied during analysis, and the measure was stopped automatically when the constant weight was reached. Protein content was determined by Kjeldahl's method [56] using a nitrogen conversion factor of 6.25 .

Crude fat is the term used to refer to the crude mixture of fat-soluble material present in a sample. The ANKOM ${ }^{\mathrm{XT} 15}$ extraction system (ANKOM Technology, Macedon, NY, USA) is a common approach designed to extract crude fat is based on the solubility of lipids in non-polar organic solvents. The analysis is achieved by measuring the loss of mass due to the extraction of fat or oil from the sample encapsulated in a filter bag. Crude fat contained within a food or feed sample can be calculated using the following formula:

$$
\text { Crude fat }(\%)=\frac{\mathrm{W} 2-\mathrm{W} 3}{\mathrm{~W} 1} \times 100
$$

where W1—original weight of the sample; W2—weight of pre-dried sample and filter bag; W3-weight of dried sample and filter bag after extraction.

Ash refers to the inorganic residue remaining after either ignition or complete oxidation of organic matter in a foodstuff. Analysis of nutritional evaluation is done by determining the ash content of the food. Ashing is the primary step when preparing a 
sample for elemental analysis. The dry ashing method, with a Muffle Furnace, determines the ash content of a variety of food products. The ash content is calculated as follows:

$$
\operatorname{Ash}(\%)=\frac{M(\mathrm{ASH})}{\mathrm{M}(\mathrm{DRY})} \times 100
$$

where $\mathrm{M}(\mathrm{ASH})$ and $\mathrm{M}(\mathrm{DRY})$ refer to the mass of the ashed sample, and the original masses of the dried samples, respectively.

Carbohydrate was calculated based on the following formula:

$$
\text { Total carbohydrat }=100-(\text { moisture }+ \text { crude fat }+ \text { ash }+ \text { crude proein })
$$

\subsubsection{Film Preparation}

The GJ at different concentrations $(1 \%, 2 \%, 4 \%, 6 \%, 8 \%, 10 \%, 20 \%$, and $30 \% v / v)$ were firstly prepared, then used for dissolving the NSPC powder $(4 \mathrm{~g} / 100 \mathrm{~mL}$ for each GJ concentration) under continuous stirring. The $\mathrm{pH}$ value was adjusted to $\mathrm{pH} 12.0$ by using $1 \mathrm{~N} \mathrm{NaOH}$. The film-forming solutions were casted onto $15 \mathrm{~cm}$ diameter polystyrene Petri dishes and allowed to dry inside the oven dryer at $30^{\circ} \mathrm{C}$ for $24 \mathrm{~h}$. Finally, the dried films were peeled off and stored inside desiccator $\left(50 \%-54 \% \mathrm{RH} \mathrm{Mg}\left(\mathrm{NO}_{3}\right)_{2} 6 \mathrm{H}_{2} \mathrm{O}\right)$ at room temperature for further analysis and use.

\subsubsection{Film Characteristics}

In order to compare the effects of various treatments to protein films, their mechanical and physical properties have to be determined. For mechanical properties, dry films were peeled off from the casting surface and conditioned at $25{ }^{\circ} \mathrm{C}$ and $50 \%$ relative humidity for $2 \mathrm{~h}$ by placing the film samples into a desiccator over a saturated solution of $\mathrm{Mg}\left(\mathrm{NO}_{3}\right)_{2}$ $6 \mathrm{H}_{2} \mathrm{O}$. Afterwards, their thickness was measured with a micrometer screw gauge $(0-25 \mathrm{~mm}$, $0.1 \mu \mathrm{m})$, at different positions for each film sample. The mechanical characteristics were measured according to ASTM D882 method [57], using a universal testing instrument (Brookfield CT3 Texture Analyzer, model CT3 50K, Brookfield, Chandler, USA), were described in the relevant literature as follows: (a) Tensile strength (TS), which is the pulling force per film cross-sectional area, required to break the film; (b) The elongation at the break for the degree to which the film can stretch before breaking; (c) Young's modulus, which provides information about a film's resistance to deformation [58]. Film strips $(1 \mathrm{~cm}$ wide) were mounted between the grips of the texture analyzer and tested with an initial grip separation of $50 \mathrm{~mm}$ and a crosshead speed of $0.5 \mathrm{~mm} / \mathrm{s}$. Three samples of each film type were tested.

Tensile strength (TS) is calculated by dividing the load at break by the original minimum cross-sectional area. The result is expressed in megapascals (MPa).

$$
\text { Tensile strength }=\frac{(\text { Load at break })}{(\text { original width })(\text { original thickness })}
$$

Percent elongation (EB) is calculated by dividing the elongation at the moment of rupture by the initial gauge length and multiplying it by 100 . The distance between the grips is used as the initial gauge length. The result is expressed in percent.

$$
\text { Percent elongation }=\frac{(\text { elongation at rupture }) \times 100}{\text { (initial gage length })}
$$

Young's modulus (YM) is calculated by drawing a tangent to the initial linear portion of the stress-strain curve, selecting any point on this tangent, and dividing the tensile stress by the corresponding strain. For the purposes of this calculation, the tensile stress was 
calculated by dividing the load by the average original cross-section of the test specimen. The result is expressed in megapascals (MPa).

$$
\text { Young's modulus }=\frac{\frac{(\text { load at point on tan gent) }}{\frac{\text { (original width) }(\text { original thickness })}{\text { (elongation at point on tan gent) }}}}{\text { (initial gage length) }}
$$

The moisture content was measured according to Galus and Lenart [59], determined by the mass loss of $1 \mathrm{~g}$ of the film after $24 \mathrm{~h}$ of oven drying at $105^{\circ} \mathrm{C}$ and was expressed as the percentage of initial film mass loss during drying. The ability of each specimen to absorb moisture was determined by measuring the weight gain of each specimen at $50 \% \mathrm{RH}$ after $24 \mathrm{~h}$. Three repetitive analyses of each film were made, and the results were expressed as mean value. A total of 3 squares $(2 \mathrm{~cm} \times 2 \mathrm{~cm})$ were cut from the films and weighed (W1), then the films were put in the oven $\left(105^{\circ} \mathrm{C}\right)$ for $24 \mathrm{~h}$ and then weighed again (W2). Then, the squares were conditioned at $25{ }^{\circ} \mathrm{C}$ and $50 \% \mathrm{RH}$ for $24 \mathrm{~h}$ by placing the film samples into a desiccator over a saturated solution of $\mathrm{Mg}\left(\mathrm{NO}_{3}\right)_{2} 6 \mathrm{H}_{2} \mathrm{O}$, after which they were weighed (W3).

Water content and uptake were calculated according to the following formulas:

$$
\begin{aligned}
& \text { Water content }(\%)=\frac{(\mathrm{W} 1-\mathrm{W} 2)}{(\mathrm{W} 1)} \times 100 \\
& \text { Water uptake }(\%)=\frac{(\mathrm{W} 3-\mathrm{W} 2)}{(\mathrm{W} 3)} \times 100
\end{aligned}
$$

The antioxidant activity of the films and the ability of films and of every single component of the film-casting solution to scavenge DPPH free radicals was assessed using the method described by Siripatrawan and Harte [60], with some modifications. Briefly, the films $(20 \mathrm{mg})$ were dissolved in water $(500 \mathrm{~mL})$. Then, sample solutions $(100 \mathrm{~mL}$ each) were mixed with $900 \mathrm{~mL}$ of DPPH methanolic solution $(0.05 \mathrm{mg} / \mathrm{mL})$. After $30 \mathrm{~min}$ in darkness at room temperature $\left(25^{\circ} \mathrm{C}\right)$, the absorbance was recorded at $517 \mathrm{~nm}$. The percentage of DPPH free radical quenching activity was determined using the following equation:

$$
\text { DPPH scavenging effect }(\%)=100-\left[\frac{(\text { Abs DPPH }- \text { Abs sample })}{(\text { Abs DPPH })} \times 100 \%\right]
$$

where Abs DPPH is the absorbance value at $517 \mathrm{~nm}$ of the methanolic solution of DPPH and Abs sample is the absorbance value at $517 \mathrm{~nm}$ for the samples. Each sample was assayed at least 3 times.

Film antimicrobial activity, the bacterial strains of Staphylococcus aureus, Pseudomonas aeruginosa, Escherichia coli, Klebsiella pneumonia, Enterococcus faecium, and Salmonella typhi were activated twice in a Mueller Hinton broth to reach a cell concentration corresponding to 0.5 turbidities at OD 600. Antimicrobial activity testing of the edible films was carried out using the agar diffusion method, according to Pranoto et al. [61]. The edible films were cut into $5 \mathrm{~mm}$ diameter discs and then placed on Mueller Hinton agar plates. These had been previously seeded with $0.2 \mathrm{~mL}$ of inoculum containing approximately $10^{5}-10^{6} \mathrm{CFU} / \mathrm{mL}$ of tested bacteria. The plates were then incubated at $37^{\circ} \mathrm{C}$ for $24 \mathrm{~h}$. Finally, the inhibition zones were observed and evaluated. Experiments were carried out in triplicate.

\subsubsection{Sweet Cherry Wrapping}

Sweet cherries of uniform size, color, without physical damage, and without fungal infections, were selected, washed with tap water, and dried at room temperature. They were randomly divided into three groups, one was wrapped (W) by sealed NSPC bags $(10 \mathrm{~cm} \times 10 \mathrm{~cm})$, one in sealed low-density polyethylene (LDPE) bags with the same size of the film, and the control was unwrapped (UW). These samples were placed at $-18^{\circ} \mathrm{C}$, the 
quality of both wrapped and control samples was evaluated during storage every week for 40 days.

\subsubsection{Physicochemical Analyses of Wrapped and Unwrapped Cherries}

Samples of 2 cherries from each bag were assessed for color, $\mathrm{pH}$, titratable acidity, and soluble solids. Color $\left(L^{*} a^{*} b^{*}\right.$ mode) was measured with a Konica Minolta CR-400 Chroma Meter, and expressed as hue angle according to the method of McGuire [62].

The $\mathrm{pH}$ values of the juice obtained by hand crushing the cherries in the bags were recorded using a $\mathrm{pH}$ meter, then it was titrated with $0.1 \mathrm{~N} \mathrm{NaOH}$ for titratable acidity (TA) which was expressed as the percentage of malic acid (\%).

The total soluble solids concentration (TSS) in the juice was measured with a refractometer (A. KRÜSS Optronic GmbH. DR6100-T, KRÜSS, Hamburg, Germany).

\section{Results and Discussion}

\subsection{Proximate Analysis of Nigella Sativa Seeds and Their Derivatives}

Using an acid-base extraction technique, protein concentrates were prepared from the defatted seed meals. Consequently, protein, moisture, fat, carbohydrate, and ash contents of the meal and concentrate protein were determined immediately after drying and then compared with raw Nigella sativa seeds (Table 1). The results showed that the protein concentration of raw seeds was $20.3 \% \pm 0.6 \%$ and after the extraction of protein, based on the acid base extraction method, it was $43.1 \% \pm 2.5 \%$. Moreover, the fat concentration of raw seeds was $45.4 \% \pm 0.5 \%$ while in the NSPC was $3.1 \% \pm 0.3 \%$ due to the defatted process that proceed to extract the Nigella sativa oil before the protein extraction.

Table 1. Proximate analysis of the Nigella sativa (NS) seeds, Nigella sativa defatted seeds cake (NSDSC), and Nigella sativa protein concentrate (NSPC), obtained from defatted seeds cake.

\begin{tabular}{cccc}
\hline Compositions (\%) & NS Seed * & NSDSC & NSPC \\
\hline Protein & $20.3 \pm 0.6$ & $34.0 \pm 2.7$ & $45.1 \pm 2.5$ \\
Moisture & $7.1 \pm 0.2$ & $7.5 \pm 0.1$ & $5.0 \pm 0.3$ \\
Ash & $7.4 \pm 0.3$ & $5.5 \pm 0.1$ & $3.7 \pm 0.7$ \\
Fats & $45.4 \pm 0.5$ & $18.2 \pm 0.5$ & $3.1 \pm 0.3$ \\
Carbohydrate & $19.7 \pm 0.4$ & $34.8 \pm 2.3$ & $43.1 \pm 1.4$ \\
\hline
\end{tabular}

* Results was according to [63].

\subsection{Nigella Sativa Edible Films Obtained in the Presence of Different Concentrations of Grape Juice}

Nigella sativa protein concentrate (NSPC) powder was dissolved with different concentrations of GJ at $\mathrm{pH}$ value 12. The initial experiments showed that the $\mathrm{pH}$ value of the film forming solution was critical to obtain very good film appearance and properties, which the NSPC films could not obtain at a pH less than 8.0 by using GJ. The NSPC-GJ film-forming solutions were casted in a Petri dish and dried for at least $48 \mathrm{~h}$. Figure 1 , showed that adding $2 \%, 4 \%, 6 \%, 8 \%$, and $10 \%$ was sufficient to obtain handleable films that were homogenized, flexible, and easily to peel off from the Petri dish, without any observed defects cracks or pores. When GJ concentrations were 1\%, 20\%, and 30\%, the film with $1 \%$ GJ was rigid, brittle, and easily broken with many cracks-which occurred because the GJ concentration was not enough to plasticize the protein polymers-while, at $20 \%$ and $30 \%$, the obtained films were sticky and difficult to separate from Petri dish due to the high concentration of GJ. Therefore, films containing $1 \%, 20 \%$, and $30 \%$ of GJ were excluded. Almost all protein-based films required plasticizing agent to reduce film fragility and obtain certain plastic properties [64,65]. 


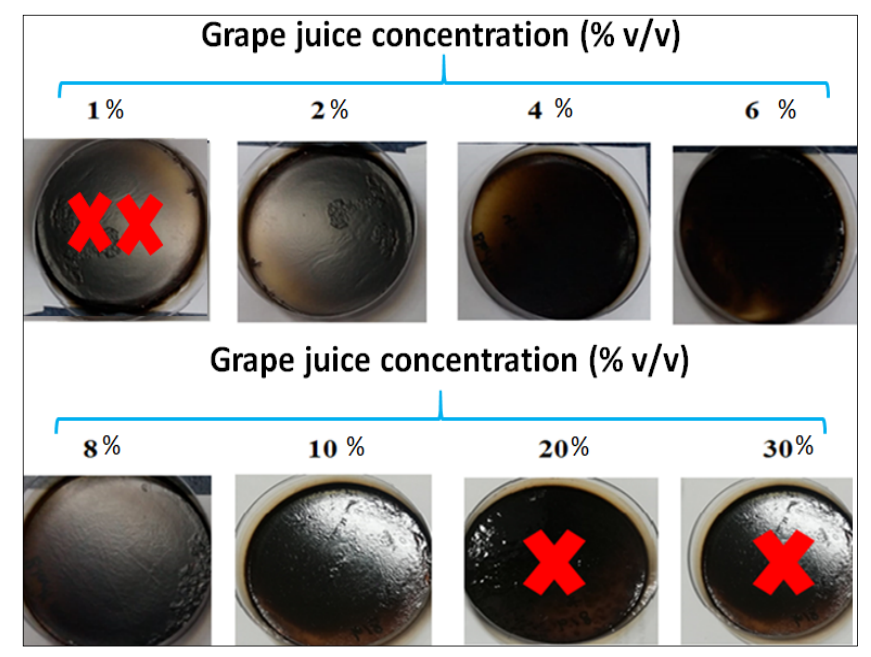

Figure 1. Images of NSDSC protein film containing different concentrations of grape juice (GJ), obtained at $\mathrm{pH}$ 12.0. Not-handleable-either brittle $(X X)$ or sticky $(X)$. Further experimental details are given in the text.

Plasticizers are molecules that are able to reduce intermolecular interactions along polymer chains, resulting in increased flexibility, extensibility, and toughness [66]. Plasticizers, on the other hand, decrease films' mechanical resistance and barrier characteristics [67]. The most common use plasticizers are polysaccharides, monosaccharides, disaccharides, or oligosaccharides. Physicochemical properties of edible films produced from whey proteins and plasticized with sucrose have been investigated by several authors, who found that these films are flexible, strong, and extremely glossy, as well as possessing good oxygen barrier qualities [68,69]; therefore, the main reason for the formation of a film based on NSDSC protein, with good physicochemical characteristics, without adding glycerol as a plasticizer, is the sugars that presented in GJ that act as plasticizers as in the case of sucrose. Veiga-Santos et al. [70] successfully obtained cassava starch films by using sucrose or invert sugar. Moreover, the pea starch-guar gum also plasticizes with different sugars [71].

The film color was black due to the seed pigmentation represented by phytomelanins, which are high-molecular weight polymers, which formed by the oxidation of phenols [72-74]. The black color of the obtained film will help to protect food products, medicines, or other products from the oxidation that may affect these products.

\subsection{Film Characterizations}

\subsubsection{Film Thickness and Mechanical Properties}

Thickness and mechanical properties of edible films are important to ensure that the films have adequate mechanical strength and integrity during transportation, handling, and storage of foods [75]. Figure 2 reports the film thickness and mechanical properties of NSDSC protein-based films, prepared with different concentrations of grape juice $(2 \%, 4 \%$, $6 \%, 8 \%$, and $10 \% v / v)$, and casted at $\mathrm{pH} 12.0$.

Results clearly indicated that there is no significant difference in film thickness by increasing the GJ concentration. The film thickness was between 76-72 $\mu \mathrm{m}$. The different GJ concentrations have significantly affected $(p \leq 0.05)$ the NSPC films TS, EB, and YM. The obtained results showed that the NSCP films TS and YM were reduced significantly when the GJ increased; whereas, film EB increased significantly until $6 \%$ GJ, and remained at almost same value at $8 \%$ and $10 \%$ GJ. Those film mechanical properties were observed by using glycerol, which is recognized as the most used plasticizer to obtain films, even in protein- or polysaccharide-based films [38,76]. Therefore, we recognized that GJ has plasticizing effect for NSPC film, based on the main ingredients of GJ, which are mainly sugars, well known for plasticizing effects. Previous work demonstrated this effect in monosaccharide, especially with glucose produced thinner films, due to the similarity of 
its chemical structure to the repeating units of polymers [71]. Veiga-Santos [70] concluded that, by increasing the sucrose or invert sugar as plasticizer to cassava starch, the film EB can be significantly increased.
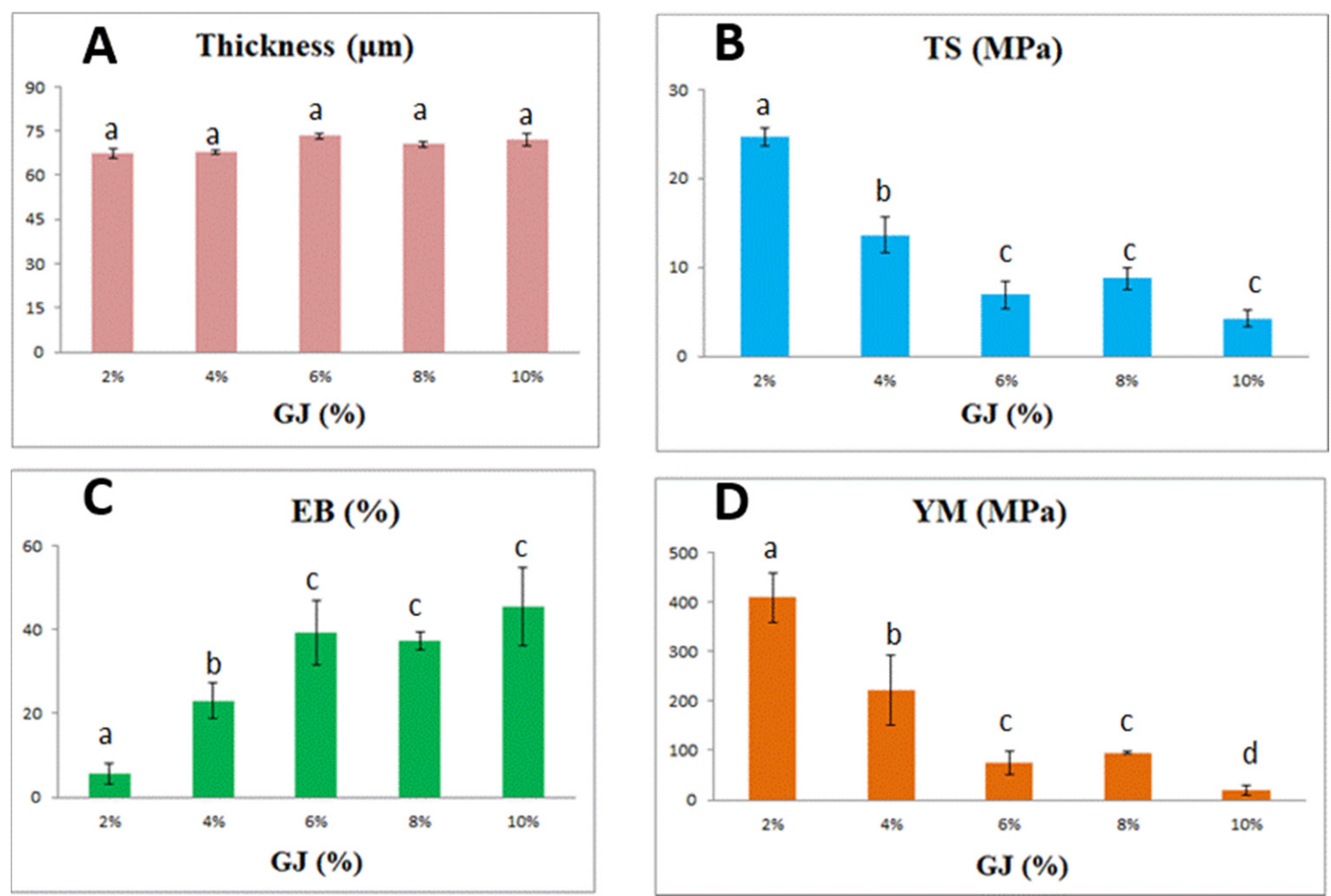

Figure 2. Demonstrates the effect of different concentrations of grape juice (GJ) on the film thickness (A) and mechanical properties (TS — tensile strength (B); EB-elongation at break (C); YM-Young's modulus (D) of NSPC edible films obtained at $\mathrm{pH}$ 12.0. Different statistical symbols (a-d) indicate significant difference between treatments $(p<0.05)$.

Table 2 compares the mechanical properties of NSDPC films incorporated with $2 \%$ and $6 \%$ GJ-as well as those of some commercial edible casing called (Viscofan NDX, Tajonar, Spain) that is obtained from gelatin-with plastic high-density polyethylene (HDPE) materials analyzed in previous studies [77]. As shown in Table 2, film prepared with a concentration of $2 \%$ of GJ had higher film thickness. Film prepared with $2 \%$ GJ almost has similar TS and YM properties as Viscofan (NDX), the commercially available material. Film prepared at $6 \%$ GJ had similar YM properties as HDPE, a commercial material.

Table 2. Thickness and mechanical properties of some commercial materials and of NSDSC protein films incorporated with $2 \%$ and $6 \%$ GJ.

\begin{tabular}{ccccc}
\hline Film & Thickness $(\boldsymbol{\mu m})$ & TS $(\mathbf{M P a})$ & EB $\mathbf{~ ( \% )}$ & YM $(\mathbf{M P a})$ \\
\hline NSPC + GJ 2\% & $67.5 \pm 1.5$ & $24.6 \pm 1.1$ & $5.6 \pm 2.3$ & $409.5 \pm 50.0$ \\
NSPC + GJ 6\% & $73.3 \pm 0.81$ & $6.90 \pm 1.5$ & $39.3 \pm 7.6$ & $74.5 \pm 23.10$ \\
Viscofan (NDX) $^{*}$ & $30.0 \pm 0.4$ & $36.6 \pm 8.1$ & $13.1 \pm 2.9$ & $356.0 \pm 29.0$ \\
HDPE * & $36.2 \pm 1.7$ & $13.1 \pm 1.4$ & $501.9 \pm 43.3$ & $75.2 \pm 2.70$ \\
\hline
\end{tabular}

* The results were obtained from previous study [77].

\subsubsection{Moisture Content and Uptake}

Among the properties of the obtained films that have been evaluated are their water moisture content and uptake, which play important roles in determining the texture and mechanical properties of edible films as coating materials, and are highly essential for potential food packaging applications [78]. Because it is well recognized that high moisture content may allow for increased bacterial and enzymatic activity or mold development 
under the available conditions, the use of edible films as a food packing material may be severely limited.

The results indicated no significant change in water content from increasing the GJ concentrations; whereas, the water uptake of the NSCP film prepared with $4 \%$ GJ has the highest water uptake $(11.1 \% \pm 0.3 \%)$, which significantly differs from the films prepared with $10 \%$ GJ $(6.4 \% \pm 1.8 \%)$ (Table 3). Plasticizing the NSCP with GJ at $4 \%$ showed the maximum water uptake that, due to the higher water-holding capacity inside the film matrixes, then gradually decreased with an increase in GJ concentration. Previous work showed that fructose plasticized cassava starch films absorb less water compared with other films obtained with urea, tri-ethylene glycol, or triethanolamine [79].

Table 3. Water content and uptake of NSPC prepared with different concentrations of grape juice (GJ).

\begin{tabular}{ccc}
\hline Film & Water Content (\%) & Water Uptake (\%) \\
\hline NSPC + GJ (2\%) & $12.1 \pm 1.4^{\mathrm{a}}$ & $7.6 \pm 1.1^{\mathrm{a}, \mathrm{b}}$ \\
NSPC + GJ (4\%) & $17.4 \pm 1.4^{\mathrm{a}}$ & $11.1 \pm 0.3^{\mathrm{a}}$ \\
NSPC + GJ (6\%) & $18.0 \pm 0.9^{\mathrm{a}}$ & $8.9 \pm 0.8^{\mathrm{a}, \mathrm{b}}$ \\
NSPC + GJ (8\%) & $15.5 \pm 3.7^{\mathrm{a}}$ & $9.8 \pm 0.7^{\mathrm{a}, \mathrm{b}}$ \\
NSPC + GJ (10\%) & $16.7 \pm 3.4^{\mathrm{a}}$ & $6.4 \pm 1.8^{\mathrm{b}}$ \\
\hline
\end{tabular}

$\overline{\mathrm{a}, \mathrm{b}}$ The values with different letters are significantly different.

There are many studies reporting the moisture content of protein-based edible films under different conditions. Bamdad et al. [80] studied the moisture content of films made from lentil protein concentrate with 50\% GLY, which was $23.15 \% \pm 1.6 \%$. Mahmoud and Savello [81] reported that the moisture content in whey protein films ranges from $26.3 \%$ to $26.5 \%$ when their glycerol content was $1.5 \%$ and increased when the concentration of glycerol increased. In a study on peanut protein concentrate film, dried at 70,80 , or $90^{\circ} \mathrm{C}$, the moisture content of peanut protein films prepared at $70{ }^{\circ} \mathrm{C}$ was $32.57 \%$ higher than for those prepared at $80{ }^{\circ} \mathrm{C}(23.84 \%)$ or $90{ }^{\circ} \mathrm{C}(14.79 \%)$ [82].

\subsubsection{Antioxidant Activity of the Film}

DPPH scavenging assay was used to indicate the antioxidant activity of the film, when the DPPH solution was mixed with the sample mixture (as a reagent), acting as a hydrogen atom donor, a stable non-radical form of DPPH is obtained with simultaneous change of the violet color to pale yellow, which was determined by using the spectrophotometry method [83]. The results showed that the DPPH scavenging activity of the films significantly increased with an increase in GJ concentration, as shown in comparison with the control films that obtained this with $30 \%$ glycerol as plasticizer (Figure 3). The film's scavenging action is connected to the fact that free radicals can react with remaining free amino $\left(\mathrm{NH}_{2}\right)$ groups to generate stable macromolecule radicals, and $\mathrm{NH}_{2}$ groups can form ammonium $\left(\mathrm{NH}_{3}\right)$ groups by absorbing a hydrogen ion from the solution [84].

In the films containing GJ, the antioxidant activity increased, due to bioactive components in grapes, which is a good natural source of antioxidants, containing many phytochemicals such as anthocyanin, catechin, epicatechin, resveratrol, and proanthocyanidin, and therefore have strong activity for scavenging free radicals [85]. The expected antioxidant nature of the active film improved as the GJ concentration in the film formulation raised. 


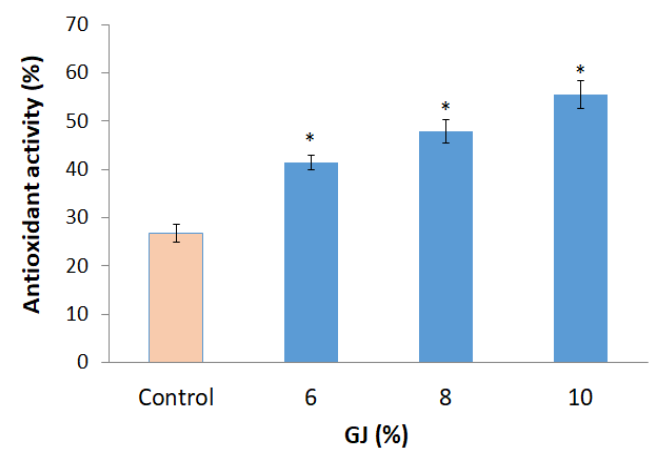

Figure 3. Effects of different concentrations of grape juice (GJ) on the DPPH scavenging activity of obtained NSPC edible films, control was the NSPC film obtained with $30 \%$ glycerol at the same $\mathrm{pH}$ value 12 . Values with $\left({ }^{*}\right)$ were significantly different compared with the control.

\subsubsection{NSDSC Protein Film Antimicrobial Activity}

The microbial strains used in this study were of medical importance. They may cause sepsis, pneumonia, and diarrhea infectious diseases, and, more importantly, they may resist conventional antibiotics. The results have shown that there was antimicrobial activity for the films as observed around the film. The inhibition zones, although irregular, increased as the GJ concentration was increased (Figure 4). However, bacterial strains showed different responses with $K$. pneumonia, which was the most affected strain. $K$. pneumonia is a biofilm-forming bacterium that uses extracellular materials to support cell growth. GJ contains active ingredients such as polyphenols that may inhibit or interfere with biofilm formation [86]. Such active ingredients in GJ were also expected to disrupt the cell wall of gram-negative bacteria. Gram-negative bacteria have complex cell walls and are more resistant to antimicrobial agents than gram-positive bacteria $[87,88]$. Similar work has found that gram-positive bacteria were more susceptible to polyphenols than gramnegative bacteria. This is an advantageous result to promote edible films and increase their functionality. With more attention given to polyphenols as antimicrobial agents, edible films enriched with polyphenols can serve functions for both preserving food and decreasing foodborne diseases. On the other hand, it was documented that polyphenol were not active against probiotics or beneficial microbiota in the gastrointestinal tract [86]. The difference between the results of current studies and other studies, in terms of antimicrobial effects, is mainly due to variations in types of polyphenols, concentrations, method of application, mode of action, and strains of target microorganisms.

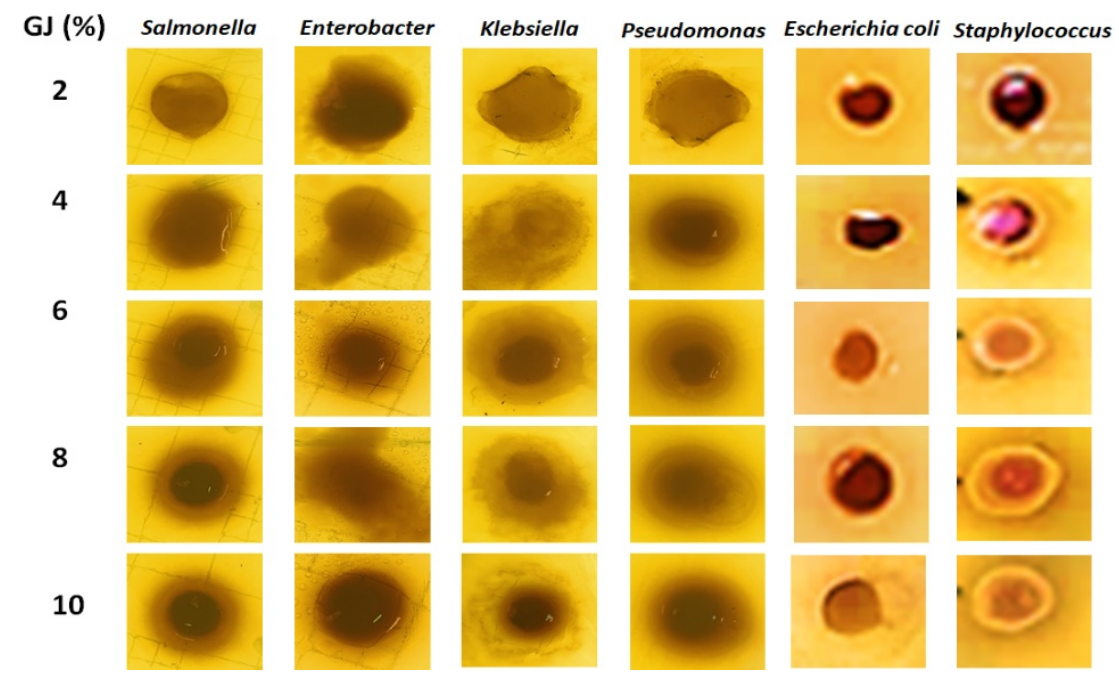

Figure 4. Effects of different concentrations of grape juice (GJ) on the antimicrobial activity of obtained NSPC edible films. 


\subsection{Effect of Wrapping with or without NSPC/GJ Film on Sweet Cherries Quality}

Effects of NSDPC with $6 \%$ GJ films and LDPE on the quality of sweet cherries was shown in (Figures 5-7). The unwrapped sweet cherries and those sweet cherries wrapped with LDPE were the controls in this experiment. The NSPC with $6 \%$ GJ was selected based on mechanical properties. Figure 5 showed the sweet cherries after removal from freezer where the unwrapped cherries were covered with small ice crystal; whereas, this was not observed in both wrapped cherries when it closed. However, the NSPC with GJ films are able to be heat-sealed by a house sealer machine.

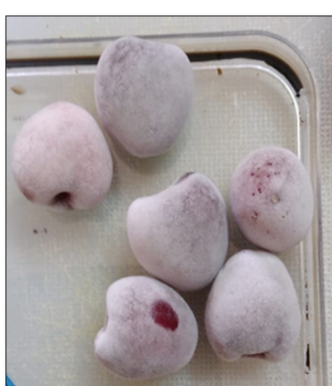

Unwrapped

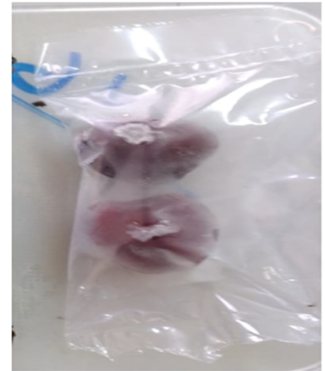

W-LDPE

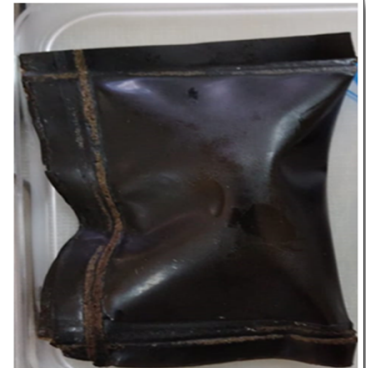

W-NSPC/GJ

Figure 5. Sweet cherries image after removing from freezer: unwrapped (control) and wrapped (W) with LDPE or NSPC with 6\% GJ.
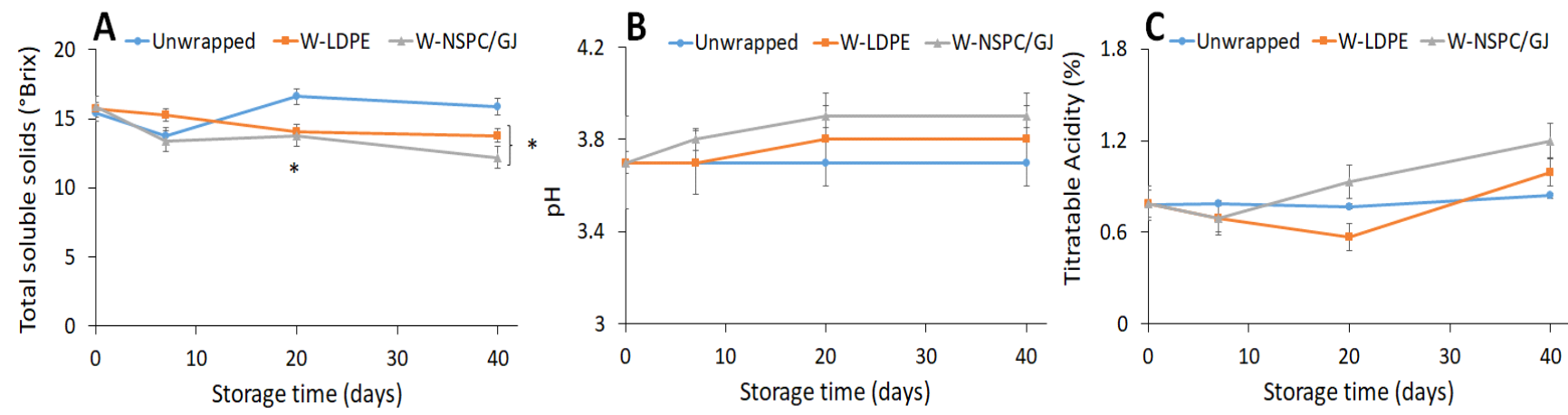

Figure 6. Effect of unwrapped (control) and wrapped (W) with LDPE or NSPC plasticized with 6\% GJ films on soluble solids content (Brix) (A), $\mathrm{pH}(\mathbf{B})$ and titratable acidity $(\mathbf{C})$, of sweet cherries stored at different storage time at $-18{ }^{\circ} \mathrm{C}$. Value with $\left.{ }^{*}\right)$ is significantly different, compared with the unwrapped sweet cherries.
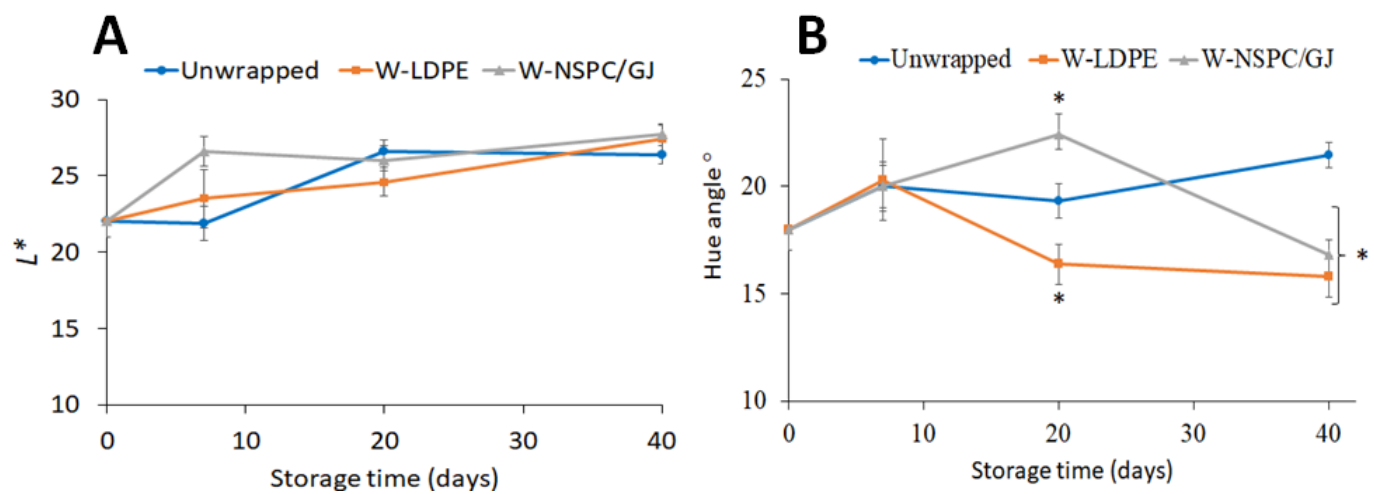

Figure 7. The effects of unwrapped and wrapped $(\mathrm{w})$ with LDPH and NSPC plasticized with $6 \%$ GJ on optical properties of sweet cherries stored at different storage times at $-18{ }^{\circ} \mathrm{C}$. Value with $\left(^{*}\right)$ is significantly different compared with the unwrapped sweet cherries. (A) $L^{*}$; (B) Hue angle.

The initial total soluble solids (TSS) were $(16.3 \pm 1.2$ Brix) of fresh cherries, indicated a good maturity as described by Kappel et al. [89]. The results showed that the TSS (Brix) 
was significantly lower compared with the control (unwrapped) after 10 days of storage at $-18{ }^{\circ} \mathrm{C}$, and no significant effect was observed between the TSS of cherries wrapped with LDPE or NSPC films in all storage times (Figure 6). One of the good juice quality indicators is the retention or minimum increase in TSS content of juice during storage [90]. The TSS decrease during storage could attribute to the respiration rate or conversion of sugar, while the increase could be explained by the breakdown of starch to sugar [91]. The results clearly indicated that the TSS concentration was stable until end of the storage period for cherries wrapped with LDPE or NSCP-GJ films. However, the titratable acidity and $\mathrm{pH}$ value of all cherries, wrapped or not, was not significantly different in any storage times.

The optical result ( $L^{*}$ and hue angle) was analyzed for the sweet cherries, the unwrapped cherries (control), and those wrapped (W) with LDPE or NSPC plasticized with $6 \% \mathrm{GJ}$, at different storage times, at freezing temperature $-18{ }^{\circ} \mathrm{C}$ (Figure 7 ). $L^{*}$ indicates lightness read from 0 (completely opaque or "black") to 100 (completely transparent or "white") [91]. The results showed that the $L^{*}$ value was not significant in any of the treatments; whereas, the hue angle results indicated that the sweet cherries wrapped with LDPE were reduced significantly compared with the ones wrapped with NSPC plasticized with GJ, or the unwrapped cherries, at 20 days of storage. Moreover, the hue angle value for the sweet cherries wrapped with NSPC showed significantly higher values at 20 days compared with the control, and the value decreased at 40 days of storage at $-18{ }^{\circ} \mathrm{C}$; additionally, there were no significant differences between the cherries wrapped with LDPE or NSPC films after 40 days of storage. Gonçalves et al. [91] and Gutiérrez-Jara et al. [92] concluded that there is a correlation between the hue angle and anthocyanins content, where the lowest value of hue angle is correlated to the cherries with highest anthocyanins content, giving a darker red color. Based on that, the obtained results indicated that the wrapping of sweet cherries is very important during freezing to protect the anthocyanins concentration in the products. However, at 40 days of storage, the unwrapped cherries hue angle value was higher compared to the 0 day hue angle value, due to the loss of the anthocyanins content. Similar results were found by Gutiérrez-Jara et al. [92], where the coated cherries showed the lower hue angle value compared with the uncoated cherries at refrigeration storage control.

\section{Conclusions}

The use of NSCP, plasticized with GJ, represents a stimulating route for creating new food packaging materials. This study indicated that NSPC and GJ appear to be interesting raw materials for the formation of functional edible packaging films. The GJ concentrations content was the most important parameter influencing the mechanical properties, as well as the physical properties, due to its plasticizing effects on the biopolymer matrix. The present study revealed, for the first time, that the use of natural GJ in combination with NSPC has a positive influence on the physicochemical traits of sweet cherries. The film proved to extend the shelf life of fresh sweet cherries by delaying changes in color, titratable acidity, total soluble solids, and $\mathrm{pH}$ during freezing storage. Moreover, the antimicrobial ability of the edible film, together with its antioxidant properties, may act synergistically to preserve food without affecting its properties, in a more environmentally friendly way.

Author Contributions: Conceptualization, M.S. and A.A.-A.; methodology, M.S., D.Y., M.A., C.V.L.G. and M.F.; software, D.Y. and C.V.L.G.; validation, L.M. and M.S.; formal analysis, M.S., M.A., A.A.-A. and M.F.; investigation, D.Y. and A.A-A.; resources, M.S., D.Y., M.A and C.V.L.G.; data curation, M.S. and D.Y.; writing — original draft preparation, M.S. and D.Y.; writing—review and editing, L.M., C.V.L.G., M.A., M.F. and M.S.; visualization, M.S.; supervision, M.S. and L.M.; project administration, M.S. and C.V.L.G.; funding acquisition, C.V.L.G., D.Y. and A.A.-A. All authors have read and agreed to the published version of the manuscript.

Funding: This work was supported by An-Najah National University (Grant No. ANNU-2021-Sc0021).

Institutional Review Board Statement: Not applicable.

Informed Consent Statement: Not applicable. 
Data Availability Statement: Original data of this work are available upon reasonable request.

Conflicts of Interest: The authors declare no conflict of interest.

\section{References}

1. Thompson, R.C.; Swan, S.H.; Moore, C.J.; vom Saal, F.S. Our plastic age. Phil. Trans. R. Soc. B 2009, 364, 1973-1976. [CrossRef]

2. Bandoim, L. Can Edible Food Wrappers Solve the Plastic Crisis? Available online: https://sciencing.com/can-edible-foodwrappers-solve-the-plastic-crisis-13717334.html (accessed on 29 February 2020).

3. Verbeek, C.J.R.; Van den Berg, L.E. Extrusion processing and properties of protein-based thermoplastics. Macromol. Mater. Eng. 2010, 295, 10-21. [CrossRef]

4. Kraśniewska, K.; Gniewosz, M. Substances with antimicrobial activity in edible films. A review. Pol. J. Food Nutr. Sci. 2012, 62, 199-206. [CrossRef]

5. Muzaffar, H.; Ajesh Kumar, V.; Chirag Maheshwari, S.; Mangraj. Biodegradable and edible film: A counter to plastic pollution. Int. J. Chem. Stud. 2020, 8, 2242-2245.

6. Shokri, S.; Ehsani, A.; Jasour, M.S. Efficacy of lactoperoxidase system-whey protein coating on shelf-life extension of rainbow trout fillets during cold storage $\left(4^{\circ} \mathrm{C}\right)$. Food Bioprocess Technol. 2015, 8, 54-62. [CrossRef]

7. Mohareb, E.; Mittal, G.S. Formulation and process conditions for biodegradable/edible soy-based packaging trays. Packag. Technol. Sci. 2007, 20, 1-15. [CrossRef]

8. Shit, S.C.; Shah, P.M. Edible polymers: Challenges and opportunities. J. Polym. 2014, 2014, 1-13. [CrossRef]

9. Fangfang, Z.; Xinpeng, B.; Wei, G.; Wang, G.; Shi, Z.; Jun, C. Effects of virgin coconut oil on the physicochemical, morphological and antibacterial properties of potato starch-based biodegradable films. Int. J. Food Sci. Technol. 2020, 55, 192-200. [CrossRef]

10. Jouki, M.; Yazdi, F.T.; Mortazavi, S.A.; Koocheki, A. Quince seed mucilage films incorporated with oregano essential oil: Physical, thermal, barrier, antioxidant and antibacterial properties. Food Hydrocoll. 2014, 36, 9-19. [CrossRef]

11. Emiroğlu, Z.K.; Yemiş, G.P.; Coşkun, B.K.; Candoğan, K. Antimicrobial activity of soy edible films incorporated with thyme and oregano essential oils on fresh ground beef patties. Meat Sci. 2010, 86, 283-288. [CrossRef]

12. Gómez-Estaca, J.; López de Lacey, A.; López-Caballero, M.E.; Gómez-Guillén, M.C.; Montero, P. Biodegradable gelatin-chitosan films incorporated with essential oils as antimicrobial agents for fish preservation. Food Microbiol. 2010, 27, 889-896. [CrossRef]

13. Moghadam, M.; Salami, M.; Mohammadian, M.; Khodadadi, M.; Emam-Djomeh, Z. Development of antioxidant edible films based on mung bean protein enriched with pomegranate peel. Food Hyd. 2020, 104, 105735. [CrossRef]

14. Lin, D.; Zhao, Y. Innovations in the development and application of edible coatings for fresh and minimally processed fruits and vegetables. Compr. Rev. Food Sci. Food Saf. 2007, 6, 60-75. [CrossRef]

15. Dubick, M.A. Historical perspectives on the use of herbal preparations to promote health. J. Nutr. 1986, 116, 1348-1354. [CrossRef] [PubMed]

16. Ali, B.H.; Blunden, G. Pharmacological and toxicological properties of Nigella sativa. Phytother. Res. 2003, 17, 299-305. [CrossRef]

17. Paarakh, P.M. Nigella sativa Linn. A comprehensive review. Indian J. Nat. Prod. Resour. 2010, 1, 409-429.

18. Salem, M.L. Immunomodulatory and therapeutic properties of the Nigella sativa L. seed. Int. Immunopharmacol. 2005, 5, 1749-1770. [CrossRef]

19. Ramadan, M.F. Nutritional value, functional properties and nutraceutical applications of black cumin (Nigella sativa L.): An overview. Int. J. Food Sci. Technol. 2007, 42, 1208-1218. [CrossRef]

20. Aljabre, S.H.; Alakloby, O.M.; Randhawa, M.A. Dermatological effects of Nigella sativa. J. Dermatol. Dermatol. Surg. 2015, 19, 92-98. [CrossRef]

21. Dubey, P.N.; Singh, B.; Mishra, B.K.; Kant, K.; Solanki, R.K. Nigella (Nigella sativa): A high value seed spice with immense medicinal potential. Indian J. Agric. Sci. 2016, 86, 967-979.

22. Meddah, B.; Ducroc, R.; Faouzi, M.E.A.; Eto, B.; Mahraoui, L.; Benhaddou-Andaloussi, A.; Martineau, L.; Cherrah, Y.; Haddad, P.S. Nigella sativa inhibits intestinal glucose absorption and improves glucose tolerance in rats. J. Ethnopharmacol. 2009, 121, 419-424. [CrossRef] [PubMed]

23. Tavakkoli, A.; Mahdian, V.; Razavi, B.M.; Hosseinzadeh, H. Review on clinical trials of black seed (Nigella sativa) and its active constituent, thymoquinone. J. Pharmacopuncture. 2017, 20, 179-193. [PubMed]

24. Leong, X.F.; Rais Mustafa, M.; Jaarin, K. Nigella sativa and its protective role in oxidative stress and hypertension. Evid. Based Complementary Altern. Med. 2013, 2013, 1-9.

25. Hosseinzadeh, H.; Parvardeh, S.; Nassiri-Asl, M.; Mansouri, M.T. Intracerebroventricular administration of thymoquinone, the major constituent of Nigella sativa seeds, suppresses epileptic seizures in rats. Med. Sci. Monit. 2005, 11, $106-110$.

26. El-Dakhakhny, M.; Barakat, M.; Abd El-Halim, M.; Aly, S.M. Effects of Nigella sativa oil on gastric secretion and ethanol induced ulcer in rats. J. Ethnopharmacol. 2000, 72, 299-304. [CrossRef]

27. Koshak, A.; Wei, L.; Koshak, E.; Wali, S.; Alamoudi, O.; Demerdash, A.; Majdy, Q.; Peter, N.; Heinrich, M. Nigella sativa supplementation improves asthma control and biomarkers: A randomized, double-blind, placebo-controlled trial. Phytother. Res. 2017, 31, 403-409. [CrossRef] [PubMed]

28. Majdalawieh, A.F.; Fayyad, M.W.; Nasrallah, G.K. Anti-cancer properties and mechanisms of action of thymoquinone, the major active ingredient of Nigella sativa. Food Sci. Nutr. 2017, 57, 3911-3928. 
29. Mollazadeh, H.; Afshari, A.R.; Hosseinzadeh, H. Review on the potential therapeutic roles of Nigella sativa in the treatment of patients with cancer: Involvement of apoptosis:-black cumin and cancer. J. Pharmacopunct. 2017, 20, $158-172$.

30. Woo, C.C.; Kumar, A.P.; Sethi, G.; Tan, K.H.B. Thymoquinone: Potential cure for inflammatory disorders and cancer. Biochem. Pharmacol. 2012, 83, 443-451. [CrossRef]

31. Ahmad, A.; Husain, A.; Mujeeb, M.; Khan, S.A.; Najmi, A.K.; Siddique, N.A.; Zoheir, A.D.; Anwar, F. A review on therapeutic potential of Nigella sativa: A miracle herb. Asian Pac. J. Trop. Biomed. 2013, 3, 337-352. [CrossRef]

32. Haseena, S.; Aithal, M.; Das, K.K.; Saheb, S.H. Phytochemical analysis of Nigella sativa and its effect on reproductive system. J. Pharm. Sci. Res. 2015, 7, 514-517.

33. Yimer, E.M.; Tuem, K.B.; Karim, A.; Ur-Rehman, N.; Anwar, F. Nigella sativa L. (black cumin): A promising natural remedy for wide range of illnesses. Evid. Based Complementary Altern. Med. 2019, 2019, 1-16. [CrossRef]

34. El-Hack, M.E.A.; Alagawany, M.; Saeed, M.; Arif, M.; Arain, M.A.; Bhutto, Z.A.; Fazlani, S.A. Effect of gradual substitution of soyabean meal by Nigella sativa meal on growth performance, carcass traits and blood lipid profile of growing Japanese quail. $J$. Anim. Feed Sci. 2016, 25, 244-249. [CrossRef]

35. Haq, A.; Lobo, P.I.; Al-Tufail, M.; Rama, N.R.; Al-Sedairy, S.T. Immunomodulatory effect of Nigella sativa proteins fractionated by ion exchange chromatography. Int. J. Immunopharmacol. 1999, 21, 283-295. [CrossRef]

36. Hosseinzadeh, H.; Taiari, S.; Nassiri-Asl, M. Effect of thymoquinone, a constituent of Nigella sativa L., on ischemia-reperfusion in rat skeletal muscle. Naunyn-Schmiedeberg's Arch. Pharmacol. 2012, 385, 503-508. [CrossRef]

37. Farah, I.O.; Begum, R.A. Effect of Nigella sativa (N. sativa L.) and oxidative stress on the survival pattern of MCF-7 breast cancer cells. Biomed. Sci. Instrum. 2003, 39, 359-364.

38. Sabbah, M.; Altamimi, M.; Di Pierro, P.; Schiraldi, C.; Cammarota, M.; Porta, R. Black edible films from protein-containing defatted cake of nigella sativa seeds. Int. J. Mol. Sci. 2020, 21, 832. [CrossRef] [PubMed]

39. Ferretti, G.; Bacchetti, T.; Belleggia, A.; Neri, D. Cherry antioxidants: From farm to table. Molecules 2010, 15, 6993-7005. [CrossRef] [PubMed]

40. Esti, M.; Cinquanta, L.; Sinesio, F.; Moneta, E.; Di Matteo, M. Physicochemical and sensory fruit characteristics of two sweet cherry cultivars after cool storage. Food Chem. 2002, 76, 399-405. [CrossRef]

41. Crisosto, C.H.; Crisosto, G.M.; Metheney, P. Consumer acceptance of "Brooks" and "Bing" cherries is mainly dependent on fruit SSC and visual skin color. Postharvest Biol. Technol. 2003, 28, 159-167. [CrossRef]

42. Alonso, J.; Alique, R. Influence of edible coating on shelf life and quality of "Picota" sweet cherries. Eur. Food Res. Technol. 2004, 218, 535-539. [CrossRef]

43. Tian, S.P.; Jiang, A.L.; Xu, Y.; Wang, Y.S. Responses of physiology and quality of sweet cherry fruit to different atmospheres in storage. Food Chem. 2004, 87, 43-49. [CrossRef]

44. Meheriuk, M.; Girard, B.; Moyls, L.; Beveridge, H.J.T.; McKenzie, D.L.; Harrison, J.; Weintraub, S.E.; Hocking, R. Modified atmosphere packaging of "Lapins" sweet cherry. Food Res. Int. 1995, 28, 239-244. [CrossRef]

45. Petriccione, M.; De Sanctis, F.; Pasquariello, M.S.; Mastrobuoni, F.; Rega, P.; Scortichini, M.; Mencarelli, F. The effect of chitosan coating on the quality and nutraceutical traits of sweet cherry during postharvest life. Food Bioprocess Technol. 2014, 8, 394-408. [CrossRef]

46. Pham, Q.T.; Mawson, R.F. Moisture migration and ice recrystallization in frozen foods. Qual. Frozen Food. 1997, 67-91.

47. Rubilar, J.F.; Cruz, R.M.S.; Silva, H.D.; Vicente, A.A.; Khmelinskii, I.; Vieira, M.C. Physico-mechanical properties of chitosan films with carvacrol and grape seed extract. J. Food Eng. 2013, 115, 466-474. [CrossRef]

48. Priyadarshi, R.; Riahi, Z.; Rhim, J.-W. Antioxidant pectin/pullulan edible coating incorporated with Vitis vinifera grape seed extract for extending the shelf life of peanuts. Postharvest Biol. Technol. 2022, 183, 111740. [CrossRef]

49. Oszmianski, J.; Lee, C.Y. Isolation and HPLC determination of phenolic compounds in red grapes. Am. J. Enol. Vitic. 1990, 39, 259-262.

50. Somers, T.C.; Ziemelis, G. Spectral evaluation of total phenolic components in Vitis vinifera: Grapes and wines. J. Sci. Food Agric. 1985, 36, 1275-1284. [CrossRef]

51. Alonso, A.M.; Guillén, D.A.; Barroso, C.G.; Puertas, B.; García, A. Determination of the antioxidant activity of wine byproducts and its correlation with polyphenolic content. J. Agric. Food Chem. 2002, 50, 5832-5836. [CrossRef] [PubMed]

52. De Campos, L.M.; Leimann, F.V.; Pedrosa, R.C.; Ferreira, S.R. Free radical scavenging of grape pomace extracts from cabernet sauvingnon (Vitis vinifera). Bioresour. Technol. 2008, 99, 8413-8420. [CrossRef]

53. Pedreschi, R.; Cisneros-Zevallos, L. Antimutagenic and antioxidant properties of phenolic fractions from Andean purple corn (Zea mays L.). J. Agric. Food Chem. 2006, 54, 4557-4567. [CrossRef] [PubMed]

54. Mirpoor, S.F.; Giosafatto, C.V.L.; Porta, R. Biorefining of seed oil cakes as industrial co-streams for production of innovative bioplastics. A review. Trends Food Sci. Technol. 2021, 109, 259-270. [CrossRef]

55. Sabbah, M.; Di Pierro, P.; Giosafatto, C.V.L.; Esposito, M.; Mariniello, L.; Regalado-Gonzales, C.; Porta, R. Plasticizing effects of polyamines in protein-based films. Int. J. Mol. Sci. 2017, 18, 1026. [CrossRef] [PubMed]

56. American Association of Cereal Chemists (AACC). Approved Methods of AACC; The Association: St. Paul, MN, USA, 2003.

57. ASTM Standard Test Method for Tensile Properties of Thin Plastic Sheeting; ASTM: West Conshohocken, PA, USA, 1995.

58. Krochta, J.M. Proteins as raw materials for films and coatings: Definitions, current status, and opportunities. Protein-Based Film. Coat. 2002, 1, 1-40. 
59. Galus, S.; Lenart, A. Development and characterization of composite edible films based on sodium alginate and pectin. J. Food Eng. 2013, 115, 459-465. [CrossRef]

60. Siripatrawan, U.; Harte, B.R. Physical properties and antioxidant activity of an active film from chitosan incorporated with green tea extract. Food Hydrocoll. 2010, 24, 770-775. [CrossRef]

61. Pranoto, Y.; Salokhe, V.M.; Rakshit, S.K. Physical and antibacterial properties of alginate-based edible film incorporated with garlic oil. Int. Food Res. J. 2005, 38, 267-272. [CrossRef]

62. McGuire, R.G. Reporting of objective color measurements. Hort. Sci. 1992, 27, 1254-1255. [CrossRef]

63. Kabir, Y.; Shirakawa, H.; Komai, M. Nutritional composition of the indigenous cultivar of black cumin seeds from Bangladesh. Prog. Nutr. 2019, 21, 428-434.

64. Dangaran, K.L.; Krochta, J.M. Preventing the loss of tensile, barrier and appearances properties caused by plasticizer crystallization in whey protein films. Int. J. Food Sci. Technol. 2007, 42, 1094-1100. [CrossRef]

65. Hernandez-Izquierdo, V.M.; Krochta, J.M. Thermoplastic processing of proteins for film formation-A review. J. Food Sci. 2008, 73, 30-39. [CrossRef] [PubMed]

66. Priyadarshi, R.; Kumar, B.; Negi, Y.S. Chitosan film incorporated with citric acid and glycerol as an active packaging material for extension of green chilli shelf life. Carbohydr. Polym. 2018, 195, 329-338. [CrossRef] [PubMed]

67. Karbowiak, T.; Hervet, H.; Léger, L.; Champion, D.; Debeaufort, F.; Voilley, A. Effect of plasticizers (water and glycerol) on the diffusion of a small molecule in kcarragennan biopolymer films for edible coating application. Biomacromolecules 2006, 7 , 2011-2019. [CrossRef]

68. Sothornvit, R.; Krochta, J.M. Plasticizer effect on oxygen permeability of betalactoglobulin films. J. Agric. Food Chem. 2000, 48, 6298-6302. [CrossRef] [PubMed]

69. Dangaran, K.L.; Krochta, J.M. Aqueous whey protein coatings for panned products. Manuf. Confect. 2003, 83, 61-65.

70. Veiga-Santos, P.; Oliveira, L.M.; Cereda, M.P.; Scamparini, A.R.P. Sucrose and inverted sugar as plasticizer. Effect on cassava starch-gelatin film mechanical properties, hydrophilicity and water activity. Food Chem. 2007, 103, 255-262. [CrossRef]

71. Saberi, B.; Chockchaisawasdee, S.; Golding, J.B.; Scarlett, C.J.; Stathopoulos, C.E. Physical and mechanical properties of a new edible film made of pea starch and guar gum as affected by glycols, sugars and polyols. Int. J. Biol. Macromol. 2007, 104, 345-359. [CrossRef]

72. Pandey, A.K.; Dhakal, M.R. Phytomelanin in compositae. Curr. Sci. 2001, 80, 933-940.

73. Eid, A.M.; Elmarzugi, N.A.; Abu Ayyash, L.M.; Sawafta, M.N.; Daana, H.I. A review on the cosmeceutical and external applications of Nigella sativa. J. Trop. Med. 2017, 2017, 1-6. [CrossRef] [PubMed]

74. Özdemir, Ö.; Keles, Y. Extraction, purification, antioxidant properties and stability conditions of phytomelanin pigment on the sunflower seeds. Int. J. Second Metab. 2017, 5, 140-148.

75. Ozdemir, M.; Floros, J.D. Optimization of edible whey protein films containing preservatives for mechanical and optical properties. J. Food Eng. 2008, 84, 116-123. [CrossRef]

76. Hopkins, E.J.; Stone, A.K.; Wang, J.; Korber, D.R.; Nickerson, M.T. Effect of glycerol on the physicochemical properties of films based on legume protein concentrates: A comparative study. J. Texture Stud. 2019, 50, 539-546. [CrossRef]

77. Porta, R.; Di Pierro, P.; Roviello, V.; Sabbah, M. Tuning the functional properties of bitter vetch (Vicia ervilia) protein films grafted with spermidine. Int. J. Mol. Sci. 2017, 18, 2658. [CrossRef]

78. Vejdan, A.; Mahdi Ojagh, S.; Adeli, A.; Abdollahi, M. Effect of $\mathrm{TiO}_{2}$ nanoparticles on the physico-mechanical and ultraviolet light barrier properties of fish gelatin/agar bilayer film. LWT Food Sci. Technol. 2016, 71, 88-95. [CrossRef]

79. Edhirej, A.; Sapuan, S.M.; Jawaid, M.; Zahari, N.I. Effect of various plasticizers and concentration on the physical, thermal, mechanical, and structural properties of cassava-starch-based films. Starch-Stärke 2017, 69, 1500366. [CrossRef]

80. Bamdad, F.; Goli, A.H.; Kadivar, M. Preparation and characterization of proteinous film from lentils (Lens culinaris). Food Res. Int. 2006, 39, 106-111. [CrossRef]

81. Mahmoud, R.; Savello, P.A. Mechanical properties of and water vapor transferability through whey protein films. J. Dairy Sci. 1992, 75, 942-946. [CrossRef]

82. Jangchud, A.; Chinnan, M.S. Peanut protein film as affected by drying temperature and ph of film forming solution. J. Food Sci. 1990, 64, 153-157. [CrossRef]

83. Blois, M.S. Antioxidant determinations by the use of a stable free radical. Nature 1958, 181, 1199-1200. [CrossRef]

84. Park, P.; Je, J.; Kim, S. Free radical scavenging activities of differently deacetylated chitosans using an ESR spectrometer. Carbohydr. Polym. 2004, 55, 17-22. [CrossRef]

85. Ramchandani, A.G.; Chettiyar, R.S.; Pakhale, S.S. Evaluation of antioxidant and anti-initiating activities of crude polyphenolic extracts from seedless and seeded Indian grapes. Food Chem. 2010, 119, 298-305. [CrossRef]

86. Daglia, M. Polyphenols as antimicrobial agents. Curr. Opin. Biotechnol. 2012, 23, 174-181. [CrossRef]

87. Aires, A.; Marques, E.; Carvalho, R.; Rosa, E.A.; Saavedra, M.J. Evaluation of biological value and appraisal of polyphenols and glucosinolates from organic baby-leaf salads as antioxidants and antimicrobials against important human pathogenic bacteria. Molecules 2013, 18, 4651-4668. [CrossRef]

88. Taguri, T.; Tanaka, T.; Kouno, I. Antimicrobial activity of 10 different plant polyphenols against bacteria causing food-borne disease. Biol. Pharm. Bull. 2004, 27, 1965-1969. [CrossRef] 
89. Kappel, F.; Toivonen, P.; McKenzie, D.L.; Stan, S. Storage characteristics of new sweet cherry cultivars. HortScience 2002, 37, 139-143. [CrossRef]

90. Bhardwaj, R.L.; Pandey, S. Juice blends-A way of utilization of under-utilized fruits, vegetables, and spices: A review. Crit. Rev. Food Sci. Nutr. 2011, 51, 563-570. [CrossRef] [PubMed]

91. Gonçalves, B.; Silva, A.P.; Moutinho-Pereira, J.; Bacelar, E.; Rosa, E.; Meyer, A.S. Effect of ripeness and postharvest storage on the evolution of colour and anthocyanins in cherries (Prunus avium L.). Food Chem. 2007, 103, 976-984. [CrossRef]

92. Gutiérrez-Jara, C.; Bilbao-Sainz, C.; McHugh, T.; Chiou, B.S.; Williams, T.; Villalobos-Carvajal, R. Effect of cross-linked alginate/oil nanoemulsion coating on cracking and quality parameters of sweet cherries. Foods 2021, 10, 449. [CrossRef] 